\title{
Application of Circumstantial Evidence in Criminal Laws in Indonesia
}

\author{
Karunia Pangestu ${ }^{1}$, Heru Suyanto ${ }^{2}$, Rosalia Dika Agustanti ${ }^{3}$ \\ ${ }^{1}$ Universitas Pembangunan Nasional Veteran Jakarta, Indonesia \\ karuniapangestu@upnvj.ac.id \\ 2 Universitas Pembangunan Nasional Veteran Jakarta, Indonesia \\ herusuyanto@upnvj.ac.id \\ 3 Universitas Pembangunan Nasional Veteran Jakarta, Indonesia \\ rosaliadika@upnvj.ac.id
}

\begin{abstract}
Introduction to the Problem: Indonesia is a constitutional state; therefore, all citizens must obey the applicable regulations. If someone commits a criminal act and is required to be brought to the court, evidence is an important thing to resolve the criminal case. A judge can determine whether the accused is guilty or not, one of the ways to determine is to consider the evidence. The law of evidence is known to have two types of evidence, namely direct evidence and indirect evidence (circumstantial evidence). Circumstantial evidence is a kind of evidence in which the relationship between the facts that occur and the available evidence can only be seen after drawing some certain conclusions. Circumstantial evidence can be very important if the other evidences are not sufficient to prove a criminal case in a court. However, the circumstantial evidences must be in accordance with the other evidences.

Purpose/Objective of the Study: The purpose of this study is to understand the circumstantial evidence in the perspective of criminal law and how it is applied in criminal cases.

Design/Methodology/Approach: The research method used in this study is a normative juridical research method, with the statutory approach and conceptual approach. The type of data used in this study is the secondary data using three legal materials, namely primary legal materials, secondary legal materials and tertiary legal materials.

Findings: Indirect evidence or Circumstantial evidence is one of the legal evidences according to Law Number 8 of 1981 concerning Criminal Procedure Law Article 188, namely the indication. However, Circumstantial Evidence is still rarely used by the system of criminal evidence in the courts in Indonesia because its validity is often questioned by the public.
\end{abstract}

Paper Type: Research Article

Keywords: The Law of Evidence; Evidence; Circumstantial Evidence, Criminal Law 


\section{Introduction}

The 1945 Constitution of the Republic of Indonesia has been amended four times. It has been emphasized in Article 1 Paragraph (3) that Indonesia is a constitutional state. According to the researchers, it emphasizes that all aspects of the nation and the people in Indonesia must always obey the applicable regulations. Law is one thing that must be upheld in the society (Harefa, 2019). The people's life will be chaotic if there is no law that governs them (Isnawan, 2018). If the regulations are violated, then there will be a sanction based on which regulation is violated. In the field of law, there is an adage called ius societies ibi ius. This adage emerges since the law exists because of the people and the relationship between the people in the society (Failin, 2017).

Regarding the law violations, Indonesia has regulated the provisions in both public and private law. In public law, the most general provisions are regulated in the Criminal Procedure Code, or often abbreviated to KUHP, and other specific regulations. Meanwhile, in private law, the regulation of civil or individual matters can be found in the Civil Code or briefly called as KUH Perdata. However, it is necessary to have the regulations that regulate the procedures of giving the punishment or sanction. Thus, the procedure of how to carry out the two laws is formed. In the field of civil law, it is formally regulated in the Herzien Inlandsch Reglement (HIR) or Revised Indonesian Reglement which has been applied to Java and Madura. Meanwhile, the cities other than Java and Madura are regulated in the Rechtreglement voor de Buitengewesten (RBG). Then, the Law No. 8 of 1981 regarding Criminal Procedure Law, which later known as the Criminal Procedure Code (KUHAP), is formed.

The broad scope of criminal law, both substantive criminal law and criminal procedural law (formal criminal law), is called as criminal law. The function of criminal procedural law is to carry out substantive (material) criminal procedural law, so it is called as formal criminal law or criminal procedural law (Hamzah, 2014). According to the Criminal Procedure Code or is abbreviated as KUHAP, the meaning of criminal procedural law is not clearly stated, but it is only explained in some parts of the criminal procedure law, namely the meaning of investigation, prosecution, trial, pretrial, verdict, legal remedies, confiscation, searches, arrests, detention, etc. (article 1 number 1- 32 KUHAP).

As stipulated in the Criminal Procedure Code, in the judicial processes, the investigation is a preparatory/preliminary process and the prosecution act also has the same objective, which is to ensure that people who are suspected/charged as the perpetrators of criminal acts are sentenced to criminal (punishment) that is worth the mistake that they have done (Latif, 2016). The criminal act is a human behavior that is defined in the law, those who are against the law should be convicted. A person who commits a criminal act will be responsible for the act. From the society's 
perspective, someone who commits a criminal act and is witnessed while doing so tends to show a normative view of the wrong behaviour (Pratiwi \& Nursiti, 2018).

The Criminal Procedure Code also regulates how the system of evidentiary while proving a certain case. The process of evidentiary contains the intention and effort to state the truth of an event, so that it can be accepted and become reasonable. Evidentiary is such a very important thing in the process of examining a criminal case in the court (Rozi, 2018). Evidentiary in a criminal case is different from the evidentiary in a civil case. Evidentiary in a criminal case aims to find the material truth, while evidentiary in a civil case aims to find the formal truth (Juniarta, 2018). Evidentiary is very important to test the truth or legal facts that actually occur (Pandiangan, 2017). In a state of law (rechtstaat) that prioritizes the supremacy of law, equality before the law and due process of law, evidentiary is one of the essences of law enforcement. Evidentiary becomes the determinant for the law of an event, legal action, legal relationship, even to determine the guilt or innocence of a person and then impose a sentence on that person (Siregar, 2018). Evidentiary is the central point of case examination in the court (Nugroho, 2017). According to Yahya Harahap, evidentiary is the provision which contains inheritance and guidelines of the methods that are justified by the law to prove the guilty indictment of the accused. Evidentiary is also a provision regarding the evidence that is justified by the law and may be used by the judges to prove the guilt.

The law of evidence is part of the criminal procedure law which regulates various types of evidence which are legal according to the law, the system in evidentiary, the conditions and procedures for submitting the evidence and the judge's authority to accept, reject and judge the evidentiary. Evidentiary of whether or not the accused commits the criminal act is the most important part of a criminal procedure. In this part too, human rights are at stake. What if a person who is being accused is found guilty of committing the accused act based on the existing evidence and the conviction of a judge while actually it is not the truth? Because of this, criminal procedural law aims to seek the material truth, contrary to civil procedural law in which it only depends on the formal truth.

The Criminal Procedure Code (KUHAP) does not provide a clear understanding of the meaning of evidentiary, but they provide an explanation of the evidence contained in article 183 which is as follows (Hamzah, 2015):

"A judge cannot convict a person unless there are at least two legal pieces of evidence and he is convinced that the criminal act actually occurs and that the accused is the one that commits the act"

Furthermore, the types of valid evidence are regulated in article 184 paragraph (1) (Hamzah, 2015):

"Legal evidence materials are:

a. the testimony of a witness;

b. information by an expert; 
c. a letter;

d. an indication;

e. the statement of a defendan."

Indication can be defined as the thing that can be used to prove the truth of an event in the court (Rusyadi, 2016). In the evidentiary process, if the evidence that has been presented is not sufficient to prove whether the accused is guilty or not, then the judge can use his independence to evaluate the strength of the evidence with the indication in certain circumstances (Kaligis, 2013).

The history of the development of criminal procedural law shows that there are several systems or theories to prove the accused. This system or theory of evidentiary varies according to time and place (country) (Hamzah, 2015). There are four theories of evidentiary which can be described as follows:

1. System or theory of evidentiary which is positively based on the law (Positief Wettelijke Bewijstheorie).

The system or theory of evidentiary which is positively based on the law (Positief Wettelijke Bewijstheorie) is based solely on law. It means that if an act has been proven in accordance with the evidence mentioned by law, then the judge's conviction in this system is not necessary at all. This system can also be called the formal evidentiary theory (formale bewijstheorie) (Ante, 2013). This system focuses on the existence of legal evidence according to the law. Although the judge is not sure of the accused's guilt, if there is evidence that is valid according to law, then the judge can sentence the accused (Ante, 2013).

Wirdjono Prodjodikoro rejects this evidentiary theory to be adopted in Indonesia, he states that how can a judge establish the truth other than by expressing his conviction about the truth. Moreover, the conviction of an honest and experienced judge may very well be in accordance with the society's beliefs.

2. The system or theory of evidentiary based solely on the judge's conviction (Conviction in Time).

This theory or system gives the freedom to the judge that it is difficult to monitor. Therefore, in this case, the accused or his lawyer is difficult to defend (Ante, 2013). According to this system, it is considered sufficient that a judge bases the evidence of a situation on his conviction alone and is not bound by any rules. In this system, the judge can use his conviction in determining whether a situation should be considered proven (Ante, 2013). This system gives judges too much freedom, so that they are difficult to monitor. In addition, legal counsel or the accused will be difficult to defend. In this case, the judge can convict the accused solely based on his conviction that the accused has been proven to have done what he is accused of (Hamzah, 2015). This system of evidentiary is widely used by the countries that use the common law system or the countries that use a jury court system such as in the United Kingdom and the United States (Mubayyinah, 2017). 
3. The system or theory of evidentiary based on the judge's conviction on logical reasons (La Conviction Raisonnee).

This theory is considered as a mediator because this theory is a combined concept of a positive evidentiary system and the judge's own conviction system. Judges' decisions are based on conviction up to a certain time limit which is supported by clear juridical arguments (Harun, 2017).

According to this system or theory, the judge can decide if someone is guilty or not based on their conviction, in which the conviction is based on valid evidentiary and is accompanied by a conclusion based on certain evidentiary rules (Ante, 2013). This system or theory of evidentiary is also known as free evidentiary, because the judge is free to state the reasons of his conviction (Hamzah, 2014).

4. The theory of evidentiary which is negatively based on the law (Negatief Wettelijk).

This theory is a mixture of positive statutory evidentiary system and Conviction Raisonnee's evidentiary. The formulation of this system of evidentiary is whether or not the accused is guilty is determined by the judge's conviction based on the method and also by valid evidences (Efendi, 2014).

According to the provisions of Article 183 of the Criminal Procedure Code, evidentiary must be based on law in which a judge can impose a sentence on someone if there is a valid evidence and also the judge's conviction which is obtained from the evidence.

Before the Criminal Procedure Code is enacted, the provision that has been stipulated in the Basic Law on Judicial Power (Law No. 14 of 1970) Article 6 is as follows:

"No one can be convicted of a crime unless the court convicts them because of a valid evidentiary according to the law that has the conviction that someone who is responsible for the criminal act has been proved guilty of an act alleged to that person" (Hamzah, 2015).

The system of evidentiary which is negatively based on the law (negatief wettelijk) should be defended for two reasons. The first reason is that there should be the conviction of the judge regarding the guilt of the accused. Therefore, the judge is able to impose a criminal sentence, and the judge should not be forced to convict a person while the judge himself is not sure of the accused's guilt. The second reason is that the system is useful if there are rules that bind the judges in formulating their conviction, so that there are certain standards that must be obeyed by the judge in conducting the trial.

Therefore, at least two valid evidences are needed to impose a sentence on the accused, so that the judge has the conviction that a criminal act does occur and that the accused is guilty of committing it. In addition to the evidence listed in the Criminal 
Procedure Code, according to the researchers, there is also an indirect evidence or Circumstantial Evidence. However, Circumstantial Evidence is still rarely used by the system of criminal evidence in the courts in Indonesia because its validity is often questioned by the public. Circumstantial Evidence itself has been used in proving the civil cases in Indonesia, namely in proving the dispute of business competition in a cartel case (Silalahi \& Edgina, 2017).

Certainly, it can be seen that the case that happened in 2004 still remains in some people's minds. At that time, a human rights activist, Munir Said Thalib, died on a flight from Jakarta to the Netherlands. After an autopsy was conducted, Arsenic poison was found in Munir's body. The evidence was that there were no witnesses that saw who gave Munir the poison, so the Central Jakarta District Court Panel of Judges found Pollycarpus guilty of assassinating Munir by using an indirect evidence or Circumstantial Evidence. A similar case also occurred in 2016. It was a case regarding the planned murder which was done by Jessica Kumala Wongso. She murdered her friend Wayan Mirna Salihin by using cyanide poison. The poison was found in Mirna's Vietnamese iced coffee. It was considered very difficult to find out who actually killed Mirna in this case, because there was no witness who saw her pouring the poison into the iced coffee that Mirna drank.

The panel of judges at the Central Jakarta District Court used Circumstantial Evidence in deciding the case of Jessica Kumala Wongso, who was finally found guilty of the planned murder of Wayan Mirna Salihin (Rahmat \& Pratiwi, 2016). However, many irregularities were found in the trial of Munir's death and the trial of the planned murder case by Jessica Kumala Wongso, so that the researcher is interested in discussing about the Circumstantial Evidence in Indonesia.

Based on the background, the researcher has compiled two prominent problems: 1 ) how is the regulation of using Circumstantial Evidence in resolving the criminal cases in Indonesia; and 2) how is the application of Circumstantial Evidence in resolving criminal cases in Indonesia.

\section{Methodology}

The research method used in this study is normative juridical research method. The approaches used in this study are the statutory approach and the conceptual approach. The type of data used in this study is the secondary data using three legal materials, namely primary legal materials, secondary legal materials and tertiary legal materials.

The primary legal materials used in this study are the 1945 Constitution of the Republic of Indonesia, Law No. 8 of 1981 concerning Criminal Procedure Law, Law No. 4 of 2004 concerning Judicial Power. Secondary legal material consists of books and scientific papers related to this research. Meanwhile, tertiary legal material is obtained through internet data related to this research. The data that have been obtained and collected through research are analyzed by using a normative approach, 
which is the data that have been collected, inventoried and analyzed using the theoretical approach and principles of criminal law that refer to legislation.

\section{Results and Discussion}

\section{The Regulation of the Use of Circumstantial Evidence in Resolving Criminal Cases in Indonesia}

Circumstantial Evidence or indirect evidence is a kind of evidence in which the relationship between the facts that occur and the available evidence can only be seen after drawing some certain conclusions. Indirect evidence must have a rational relevance, so that it can be used in the court. It will make the facts proven clearly.

According to the researchers, the law does not clearly mention indirect evidence or Circumstantial Evidence. However, this indirect evidence can be referred as one of the valid evidences according to the Criminal Procedure Code, namely the indication. Indication is an act, event, or situation in which because of its compatibility, either between one and the other or with the criminal act itself, indicates that a criminal act has occurred and who the perpetrator is. In Paragraph 2, that action, event, or condition can only be obtained from: a. witness' statements; b. letters, and; c. statement of the accused (article 188 KUHAP).

According to Yahya Harahap, the formulation of the article is difficult to understand. Perhaps the formula can be written by adding a few words to it. With the addition of these words, it can be written as follows:

"An indication is a signal that can be withdrawn from an action, event or condition in which the signal has compatibility between one another and the signal has compatibility with the crime itself, and from the corresponding signal, it produces or realizes a guideline that forms the reality of the occurrence of a criminal act and that the accused is the one who is guilty."

Contrary to other evidences, namely witness' statements, expert's statements, letters and statements of the accused, the indication is obtained from the statements of the witnesses, letters, and statements of the accused. It means that the indication is not a direct evidence (indirect bewijs). Therefore, many people think that indication is not an evidence (Alfitra, 2011).

The role of the indication as the determinant of whether or not the accused will be sentenced cannot be ignored, for example, evidence from the expert's statement, documentary evidence as well as evidence from the accused's statement (Manaroinsong, 2016). According to Eddy O.S. Hiariej, in the context of the legal theory of evidence, the indication is a circumstantial evidence or indirect evidence which is complementary or it can be called as accessories evidence. It means that an indication is not an independent evidence, but it is a secondary evidence obtained from the primary evidence, in this case they are statements of witnesses, letters and statements of the accused (Hiariej, 2012). 
The main tasks of the judges are to examine, adjudicate and settle the cases presented to them, so that the judges only have one choice which is to examine and decide on the case to assist the justice seekers. The judge gives a decision based on the justice. This means that the judge must judge according to the law, so that the judge must be familiar with the laws and events, and a judge is also considered to know the law on various concrete events (ius curia novit) (Kusmiati, 2001). In using the indication as an evidence, a judge must look for a relationship between an act, incident or situation that occur in order to draw a conclusion, so that the judge can decide whether or not the criminal act committed by the accused is proven or not. In this case, according to article 183 KUHAP, a judge must be careful in implementing a decision through the indication (Prameswari, 2015). If not used appropriately, the results will be arbitrary, because these decisions are dominated by excessive and subjective judgments.

The judge has full authority and subjectivity of the indication when examining the case. The judge can draw the conclusions about the evidentiary as an indication and he must also relate one evidence to another. Therefore, the indication can only be used if the available evidence cannot convince the judge about the occurrence of a criminal act and that the accused is the one who commits it (Prameswari, 2015). Indication is used if other evidences (letters, witness' statements, the accused's statements) have not convinced the judge. Thus, the existence of indication will strengthen the judge's conviction that it is true that a criminal act has occurred and the accused is indeed the perpetrator (Wijayanto, 2015).

If the judge is not yet convinced, there are three possibilities that cause it. First, the existing evidence does not meet the minimum requirements, namely two pieces of evidence. Second, it has fulfilled the minimum of evidence, but has produced facts that each stands on its own. If this is the case, the indication can meet the minimum requirements of evidence. Third, valid evidence is sufficient, but the judge is not yet sure about the occurrence of a criminal act and it is the accused who commits it. In this case, indication is used to convince the judge (Wijayanto, 2015).

The Criminal Procedure Code can justify the judge to make a thought based on events, actions, or circumstances encountered by the judge in the witness' statements, letters, or statements of the accused. Precisely, the researcher can say that the judge can make a basis to view the fact as evidence (Alfitra, 2011). This is in accordance with article 113 HIR paragraph (3). That article emphasizes on applying instructions as evidence that the assessment of the strength of an evidentiary in any particular situation is left to the judge's consideration after the judge has conducted a thorough examination (Alfitra, 2011).

In the Draft Law of KUHAP, the indication is changed to become the judge's observation. This is written in article 175 paragraph (1) of the 2010 Draft Criminal Procedure Code, which is as follows:

"Valid evidences include: 


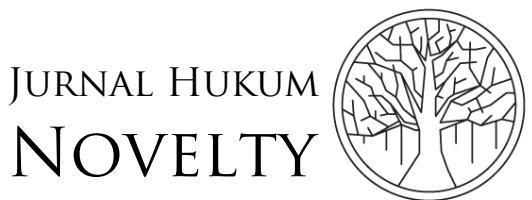

Volume 12, Issue 01, 2021, pp. 54-66

P-ISSN: $1412-6834$

E-ISSN: 2550-0090
a. Evidence;
b. Letters;
c. Electronic documents;
d. Statements of the expert;
e. Statements of the witness;
f. The accused's statements; and
g. Judge's observation."

Meanwhile, in Article 182 of the Draft Law of Criminal Procedure Code, it states the same sentences like in the Article 188 paragraph (1) and paragraph (3) of the Criminal Procedure Code and only omits the word 'indication'. This happens because there are many cases where the judges fail to prove the indictment of the prosecutor due to a lack of evidence. Meanwhile, the mandate of Article 10 of Law Number 48 Year 2009 concerning Judicial Power which is as follows: "The court is prohibited from refusing to examine, try and decide a case filed on the pretext that the law does not exist or is unclear but is obliged to examine and judge it"

The observation of evidence by the judges can provide flexibility for the judges in deciding every case submitted to them and they cannot create legal uncertainty with article 10 of Law Number 48 of 2009 concerning Judicial Powers.

\section{Application of Circumstantial Evidence in Resolving Criminal Cases in Indonesia}

Circumstantial evidence is rarely used in settling the criminal cases in Indonesia. However, that does not mean there are no criminal cases that use circumstantial evidence as a tool to prove by the judges in the court. One of the most famous cases using this indirect evidence system is the case of the planned murder of Jessica Kumala Wongso against Wayan Mirna Salihin by poisoning Mirna's Vietnamese coffee.

In the case, the Panel of Judges emphasize that there should not be a witness who sees someone committing a criminal act. Judges can obtain the evidence from circumstantial evidence. The suspicion against Olivier cafe that might have committed the murder is also explained by the judge logically. The council thinks that if it is true that Olivier cafe has planned the murder, then surely Vietnamese iced coffee would have been discarded. This means that cyanide is already in the Vietnamese iced coffee before the investigators conduct the investigation.

Application of circumstantial evidence in a country that adopts a legal system that is different from Indonesia is already legal and often used in settling a case. For example, in the case of Scott Peterson in California (Dillon, 2013). However, contrary to Indonesia which uses civil law understanding, this indirect evidence is very difficult for some people to accept due to the legal system and understanding of the law in the provisions of the judiciary or the Panel of Judges who are active in trials and decide based on applicable laws. Therefore, according to article 183 KUHAP, a judge can impose a sentence on a person with a minimum of two valid evidences and the judge's 
conviction. Indication can be used as a basis for the judge's consideration with a minimum of another evidence and the conviction of the judge. There are also people who say that this circumstantial evidence can be categorized as a real evidence or physical evidence. This evidence must be strengthened by testimony or the testimony can be strengthened by other evidences. In the context of evidentiary, it is known as corroborating evidence which literally means that the evidence is strengthened by the testimony before being considered by a judge (Hiariej, 2012).

What is meant by real evidence in the form of circumstantial evidence is that it does not directly prove the existence of the facts concerned, but that evidentiary can only be drawn from a conclusion that the facts about a particular object are true, so that it can also be concluded that other facts are also true. For example, in the case of proving a child from a father, the similarity of the face between the child and the father can be the circumstantial evidence that there is indeed a blood relationship between the child and the father (Fuadi, 2012).

Physical evidence is usually called as real evidence. Real evidence is the kind of evidence that is closely related to whether or not the accused is guilty (Lokas, 2015). Although a real evidence is also a source of evidence, the strength of real evidence is different from evidence. Real evidence can only be used as a material to form evidence and can be used to strengthen the judge's conviction. Based on the references that can be used to reconstruct the indication imitatively, it has been determined in Article 188 paragraph (2) of the Criminal Procedure Code, namely witness' statements, letters and statements of the accused. Based on those three evidences, the judge can process the indication from the three evidences based on the suitability, action, incident or condition that can be found and shaped (Sukarna, 2015). Therefore, the judge should not seek the indication randomly from all sources.

The statement of witnesses which is included in the indication is from the witness who is not an evidence as stipulated in article 185 (1) Criminal Procedure Code, namely:

1. Testimonium de auditu, namely the testimony or statement from other people. As part of the witness' testimony, the Testimonium de auditu is a valid evidence as an indication. Although it is not included in formal legal terms, Testimonium de auditu is used and its existence is recognized by the Criminal Procedure Code (Situmorang, 2020).

2. Opinions, thoughts and ideas.

3. Witnesses that are not sworn in (outside the trial).

4. Having a family relationship with the accused, unless the person concerned wishes to be with the prosecutor and the accused, the witnesses' testimony then may be heard and then sworn in the court.

5. Children under the age of 15 years, those who have never been married, and people who pretend to have amnesia. 


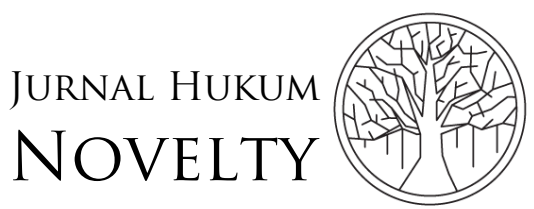

Volume 12, Issue 01, 2021, pp. 54-66

Regarding documentary evidence, the letter that can be used as an indication is an ordinary letter which has the evidentiary value of indication if the letter is in accordance with other valid evidences. Meanwhile, official letters/authentic letters that are submitted and read out in the trial are documentary evidence which has its own evidentiary value, so it is not included in letter evidence which can be used as an indication. This is stated in article 187-point $\mathrm{d}$ of the Criminal Procedure Code which is as follows: "another letter can only be valid if it has something to do with the contents of other evidences". In accordance with the negative evidentiary used by the Criminal Code, there must be the judge's conviction on the evidence that is presented, so the judge is free to use or set aside the letter (Pretiwi \& Satrio, 2010).

The statement of the accused that can be used as an indication is the testimony of the accused which is said outside the trial. The statement of the accused that is said outside the trial can be used to help to find evidence in deciding a case at trial. However, the statement must be supported by other evidences and is compatible with other evidences which are in accordance with the matter that is being accused. The statement of the accused in the context of evidentiary law in general can be equated with confession evidence (Werluka, 2019). The statement of the accused is written in article 189 paragraph (2) of the Criminal Procedure Code which is as follows: "The statement of the defendant which is said outside the trial can be used to help to find evidence at trial as long as it is supported by a valid evidence concerning the matter that is being accused."

In the case of the planned murder of Jessica Kumala Wongso, based on the evidence collected by the investigator in the form of testimony from the witnesses who are at the scene of the case, letter evidence which is in the form of an electronic document from the Olivier cafe CCTV recording shows some irregularities in Jessica's movements, as well as the evidence of Jessica's conversation with the victim on their Whatsapp Group, the judge in her observations is able to judge the suitability of the evidence and draw the conclusion that it is indeed Jessica who kills the victim.

\section{Conclusion}

Circumstantial Evidence or indirect evidence is one of the valid evidences according to Law Number 8 of 1981 concerning Criminal Procedure Law Article 188, namely indication. In using the indication as an evidence, a judge must look for a relationship between an act, incident or situation that has occurred in order to draw a conclusion, so that the judge can decide whether or not the criminal act committed by the accused is proven or not. In this case, the judge must be careful in applying the verdict through this directive evidence.

In its application in Indonesia, judges who use this indirect method of evidence are based on references that can be used to reconstruct directive evidence in a limitative manner as specified in Article 188 paragraph (2) of the Criminal Procedure Code, namely witness' statements, letters and statements of the accused. Therefore, the judge should not seek the indication randomly from all sources. 


\section{References}

Alfitra. (2011). Hukum Pembuktian dalam Beracara Pidana, Perdata, dan Korupsi Di Indonesia: Edisi Revisi (Edisi Revi). Raih Asa Sukses.

Ante, S. (2013). Pembuktian Dan Putusan Pengadilan Dalam Acara Pidana. Lex Crimen, II(2), 98-104.

Dillon, L. (2013). Still Stone Cold Guilty: The Murder Case Against Scott Lee Peterson. Createspace Independent Pub.

Efendi, T. (2014). Dasar-Dasar Hukum Acara Pidana (Perkembangan dan Pembaharuan di Indonesia). Setara Press.

Failin. (2017). Sistem pidana dan pemidanaan di dalam pembaharuan hukum pidana indonesia. Jurnal Cendekia Hukum, 3(1), 14-31.

Fuadi, M. (2012). Teori Hukum Pembuktian (Pidana dan Perdata). PT. Citra Aditya Bakti.

Hamzah, A. (2014). Hukum Acara Pidana Indonesia: Edisi kedua (Edisi Kedu). Sinar Grafika.

Hamzah, A. (2015). KUHP dan KUHAP. Rineka Cipta.

Harefa, S. (2019). Penegakan Hukum Terhadap Tindak Pidana di Indonesia melaui Hukum Pidana Positif dan Hukum Pidana Islam. UBELAJ, 4(1), 35-58.

Harun, N. (2017). Proses Peradilan Dan Arti Sebuah Keyakinan Hakim dalam Memutus Suatu Perkara Di Pengadilan Agama Manado. Jurnal Ilmiah Al-Syir'ah, 15(2), 167-192.

Hiariej, E. O. S. (2012). Teori dan Hukum Pembuktian. Erlangga.

Isnawan, F. (2018). Pandangan Yuridis Sosiologis Fenomena Street Justice Di Dalam Kehidupan Bermasyarakat. Jurnal Hukum Novelty, 9(1), 17-35.

Juniarta, I. B. G. A. (2018). Legalitas Rekaman Circuit Closed Television (CCTV) Dalam Proses Pembuktian di Persidangan. Jurnal Magister Hukum Udayana (Udayana Master Law Journal), 7(1), 36-50.

Kaligis, J. (2013). Penerapan Alat Bukti Petunjuk oleh Hakim dalam Menjatuhkan Putusan Tindak Pidana Pembunuhan. Lex Crimen, II(4), 23-32.

Kusmiati, n. ike. (2001). Kekuatan Pembuktian Surat Berita Acara Pemeriksaan Tersangka Yang Dijadikan Alat Bukti. Jurnal Yudisial, IV(01), 62-74.

Latif, D. H. (2016). Peran Alat Bukti Petunjuk dalam Tindak Pidana Umum menurut KUHAP. Lex Administratum, IV(3), 206-212.

Lokas, R. (2015). Barang Bukti dan Alat Bukti dalam Kitab Undang-Undang Hukum Acara Pidana. Lex et Societatis, III(9), 124-129.

Manaroinsong, M. (2016). Penerapan Alat Bukti Petunjuk oleh Hakim dalam Penjatuhan Putusan Tindak Pidana Perkosaan. Lex et Societatis, IV(9), 5-14.

Mubayyinah, F. (2017). Perbandingan Sistem Hukum Pembuktian dalam Penanganan Perkara Tindak Korupsi dengan Perkara Tindak Pidana Lainnya. AL HIKMAH Jurnal Studi Keislaman, 7(1), 36-44.

Nugroho, B. (2017). Peranan alat bukti dalam perkara pidana dalam putusan hakim menurut kuhap. Jurnal Yuridika, 32(1), 17-36.

Pandiangan, H. J. (2017). Perbedaan hukum pembuktian dalam perspektif hukum acara pidana dan perdata. Jurnal Hukum Tô-Râ, 3(2).

Prameswari, N., Samirah, \& Yuliati, S. W. (2015). Kedudukan Alat Bukti Petunjuk di Ranah Hukum Acara Pidana. Jurnal Verstek, 3(2), 1-10.

Pratiwi, V., \& Nursiti. (2018). Tindak Pidana Pembunuhan Berencana yang Dilakukan Secara Bersama-Sama. JIM Bidang Hukum Pidana, 2(November), 679-688.

Pretiwi, V. W. A., \& Satrio, C. G. (2010). Implikasi Penggunaan Alat Bukti Fotokopi 
Surat Dalam Perkara Korupsi. Jurnal Verstek, 3(1), 108-118.

Rahmat, B., \& Pratiwi, P. S. (2016). Vonis Jessica Bersalah, Hakim Pakai Bukti Tak Langsung. Https://Www.Cnnindonesia.Com/Nasional/20161027180543-1218489/Vonis-Jessica-Bersalah-Hakim-Pakai-Bukti-Tak-Langsung.

Rozi, F. (2018). Sistem Pembuktian Dalam Proses Persidangan Pada Perkara Tindak Pidana. Jurnal Yuridis UNAJA, 1(2), 19-33.

Rusyadi, I. (2016). Kekuatan alat bukti dalam persidangan perkara pidana. Jurnal Hukum PRIORIS, 5(2), 128-134.

Silalahi, U., \& Edgina, I. C. (2017). Pembuktian Perkara Kartel Di Indonesia Dengan Menggunakan Bukti Tidak Langsung (Indirect Evidence). Jurnal Yudisial, 10(3), 311-330.

Siregar, M. (2018). Bukti Tidak Langsung (Indirect Evidence) dalam Penegakan Hukum Persaingan Usaha di Indonesia. 13(2), 187-200.

Situmorang, N. G. (2020). Kedudukan Hukum (Legal Standing) Keterangan Saksi Testimonium De Auditu Sebagai Alat Bukti Yang Sah Pra dan Pasca Putusan Mahkamah Konstitusi Nomor : 65/PUU-VIII/2010. PALAR (Pakuan Law Review), 06(02), 102-122.

Sukarna, K. (2015). Alat Bukti Petunjuk dalam Proses Peradilan Pidana. Prosiding Seminar Nasional Pengembangan Epistemologi Ilmu Hukum, 350-376.

Werluka, L. (2019). Alat Bukti yang Sah dalam Pembuktian menurut Undang-Undang Nomor 8 Tahun 1981 Tentang Hukum Acara Pidana (KUHAP). Jurnal Belo, 4(2), 228-248.

Wijayanto, T. (2015). Alat Bukti Petunjuk Dalam Penyelesaian Perkara Pidana (Studi Kasus Di Wilayah Hukum Pengadilan Negeri Surakarta). Fakultas Hukum Universitas Muhammadiyah Surakarta, 1-15. 